\title{
SECOND GENERATION WASTE PACKAGE DESIGN STUDY
}

\author{
Final Report
}

September $1^{\text {st }}, 2006$ to March 31 ${ }^{\text {st }}, 2007$

Task No: ORD-FY06-023

-submitted to-

United States Department of Energy

Office of Civilian Defense Radioactive Waste Management

Yucca Mountain Project

1551 Hillshire Drive, Suite A

Las Vegas NV 89134-6321

and

Harry Reid Center

University of Nevada, Las Vegas

4505 Maryland Parkway

Las Vegas Nevada 89154-4009

\author{
-submitted by- \\ Metallurgical and Materials Engineering \\ Mail Stop 388 \\ $1664 N$. Virginia Street \\ College of Engineering \\ University of Nevada, Reno \\ Reno NV 89557
}

J. S. Armijo (PI), M. Misra (Co-PI) and Piyush Kar (Post-Doctoral Scholar)

June 28, 2007 


\section{Statement of Work}

The principal purpose of the cooperative agreement is to develop and continue providing the public and the Office of Repository Development (ORD) of the U.S. Department of Energy's (DOE) Office of Civilian Radioactive Waste Management (OCRWM) with an independently derived, unbiased body of scientific and engineering data concerning the study of Yucca Mountain as a potential high-level radioactive waste repository. Under this agreement, the Nevada System of Higher Education (NSHE), formerly the University and Community College System of Nevada (UCCSN), will perform scientific or engineering research, and maintain and foster collaborative working relationships between government and academic researchers. The following describes the objectives of Project Activity 023 "Second Generation Waste Package Design Study” under the cooperative agreement.

The objectives of this project activity are:

- to review the current YMP baseline environment and establish corrosion test environments representative of the range of dry to intermittently wet conditions expected in the drifts as a function of time.

- $\quad$ to demonstrate the oxidation and corrosion resistance of A588 weathering steel and reference Alloy 22 samples in the representative dry to intermittently dry conditions.

- to evaluate backfill and design features to improve the thermal performance analyses of the proposed second-generation waste packages using existing models developed at UNR.

The work plan for this project activity consists of three major tasks:

Task 1. Definition of expected worst-case environments (humidity, liquid composition and temperature) at waste package outer surfaces as a function of time, and comparison with environments defined in the YMP baseline.

Task 2. Oxidation and corrosion tests of proposed second-generation outer container material.

Task 3. Second Generation waste package thermal analyses.

This project activity is an essential part of the program to enhance the collaborative ongoing research between the NSHE and the ORD during the five-year period of the cooperative agreement. 
Progress for the period 10/01/06 - 03/31/07

Estimated percent completion by subtask is summarized below, and in Appendix 1 to this report.

\begin{tabular}{|r|l|c|}
\hline Task & Description & \% Complete \\
\hline 1 & Definition of expected worst case environments & $20 \%$ \\
\hline 2 & $\begin{array}{l}\text { Oxidation and corrosion tests of proposed second generation } \\
\text { outer container material. }\end{array}$ & $15 \%$ \\
\hline 3 & Second Generation waste package thermal analyses. & $30 \%$ \\
\hline
\end{tabular}

\section{SUBTASK 1 - DEFINITION OF EXPECTED WORST CASE ENVIRONMENTS}

Thermal analysis for a 5000 year period in the Yucca Mountain Waste repository environment is complete. Calculations were performed to determine the maximum oxide thickness that would be formed on the surface of the A588 steels as container wall material in the Second Generation waste packages in the first 5000 year of emplacement. The details are reported in the first and second quarterly reports [1] [2].

\section{SUBTASK 2 - OXIDATION AND CORROSION TESTS Test Materials}

The A588 test material was acquired from the Central Steel Inc. The compositional and mechanical property certificates were provided by the supplier, and independent testing was conducted to verify the alloy content and mechanical properties. Details are reported in the second quarterly report. The Alloy 22 test material along with composition and mechanical property certificates was obtained from ongoing DOE sponsored research programs at the University of Nevada, Reno.

\section{Isothermal Oxidation Tests}

A thermal gravimetric apparatus (TGA) was purchased from the Shimadzu Inc. for conducting isothermal oxidation tests in air at elevated temperatures. Isothermal oxidation tests in the TGA and also in box furnace environments, for the both the A588 and the Alloy 22 materials, were ongoing at termination. Microstructure, metallographic and electrochemical characterization studies of the oxide scales were also ongoing. Test data were recorded and retained in project files.

\section{Thermal Gravimetric Analysis}

The objective of the TGA testing was to determine the optimum times and temperatures for growing oxide scales that are equivalent in thickness to those which would form during a 10,000 year emplacement in the Yucca Mountain repository. The goal of this effort was to grow oxides of equivalent composition and structure in reasonable times by oxidizing test specimens at significantly higher temperatures than expected in the repository. TGA scoping tests were conducted at 600, 700, 800 and 900 ${ }^{\circ} \mathrm{C}$. An important conclusion from these high temperature test data is that temperatures 
above $600{ }^{\circ} \mathrm{C}$ are not favorable due to spalling of the iron oxide scale (reported in the second quarterly report).

Subsequent isothermal oxidation tests were performed for 10 to 20 day time periods at 475 to $600{ }^{\circ} \mathrm{C}$. Results are summarized in Figure 1. Plots of weight gain per unit area vs. square root of time for the A588 steel in the dry air environment at four different temperatures, $475,500,575$ and $600{ }^{\circ} \mathrm{C}$ show that parabolic oxidation behavior was occurring at temperatures up to $575{ }^{\circ} \mathrm{C}$. The measured oxidation at $600{ }^{\circ} \mathrm{C}$ was fitted to a second order polynomial. The parabolic oxidation rate constants were determined from the slopes of the data for each temperature. Since the $600{ }^{\circ} \mathrm{C}$ were not linear over the entire time range, the slope for the first 100 hours was used as a pseudo rate constant.

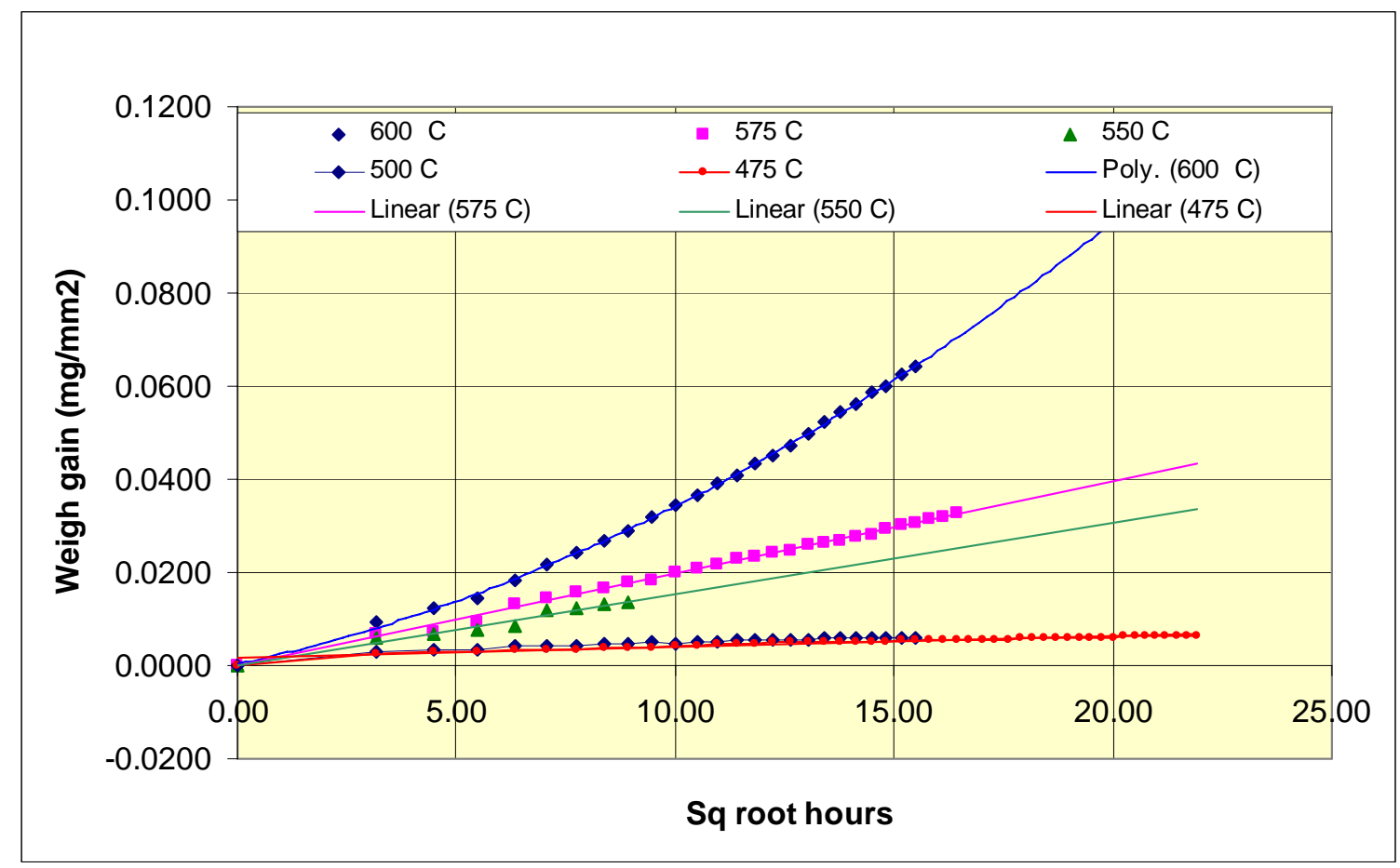

Figure 1. Plot of weight gained per unit area vs. square root of time. Straight line fit can be observed from the data confirming parabolic kinetics at temperatures less than 600 .

The logarithm of the rate constants plotted against the inverse of the absolute oxidation temperature, are shown in Figure 2. The slope of the straight line fitting the data multiplied by the gas constant yielded the activation energy for the oxidation of the A588 material in the 475 to $600^{\circ} \mathrm{C}$ regime.

The activation energy, as obtained from these data was 116 kilojoules per mol. This is 30\% higher than the value reported in literature Chang [3], i.e. 91 kilojoules per mol. The higher activation energy determined for A588 in the present study is probably more representative since the Chang studies were limited to short term (24 hour) tests compared to the 240 hour to 480 hour tests in this study. 


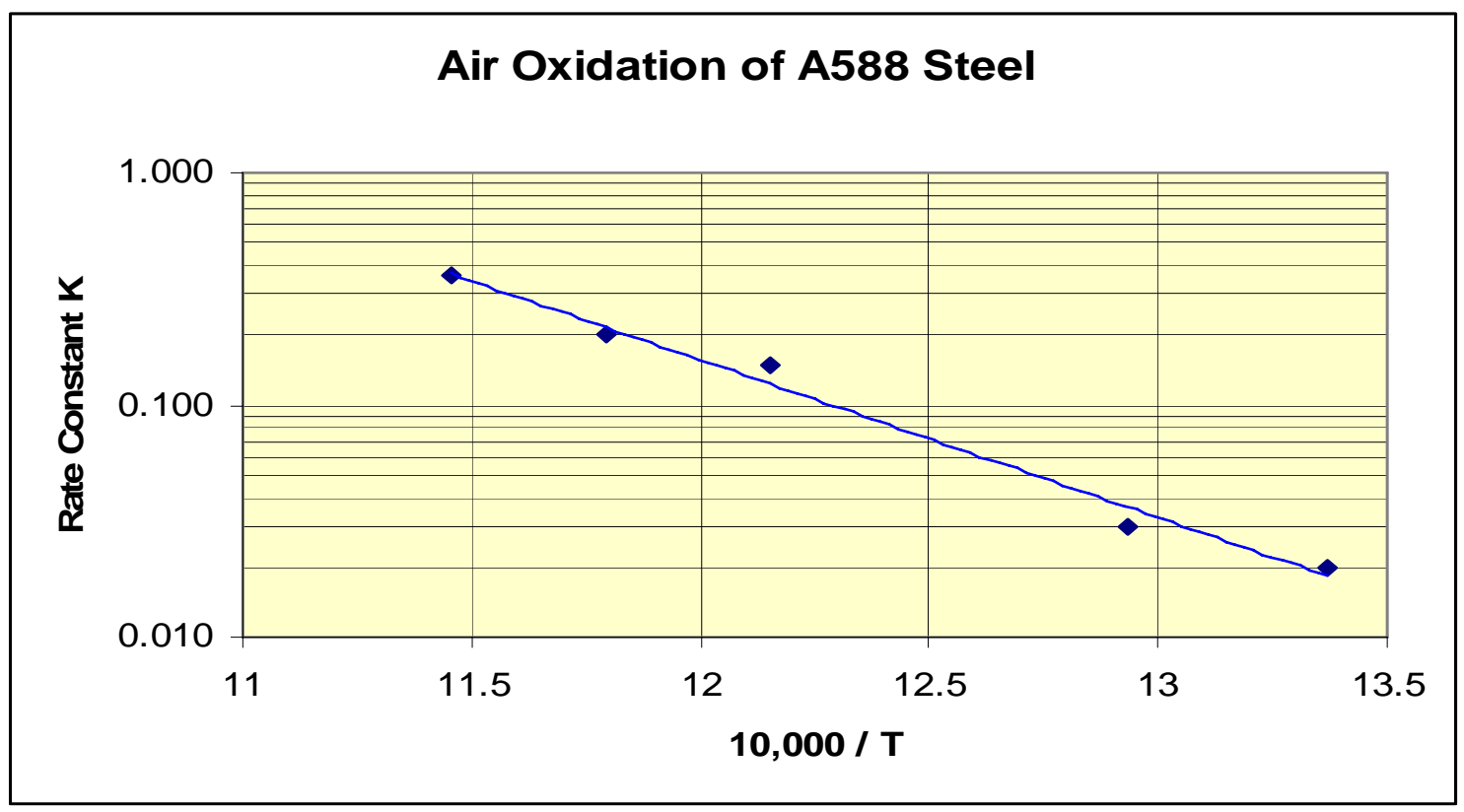

Figure 2. Plot of measured rate constants in $\left(\mathrm{mg} / \mathrm{cm}^{2}\right.$ hour $\left.^{1 / 2}\right) \mathrm{vs}$. inverse of the absolute temperatures, for dry air oxidation of the A588 steel, at 475, 500, 550, 575 and $600{ }^{\circ} \mathrm{C}$.

\section{Drip Testing}

An initial set of design requirements for the drip corrosion experimental apparatus was developed. Details of the requirements for the apparatus are provided in the first quarterly report. A conceptual design based on these requirements was in progress at project termination

\section{SUBTASK 3 - SECOND GENERATION WASTE PACKAGE THERMAL ANALYSIS}

\section{Thermal Analysis}

The thermal transient of the Second Generation waste packages was performed for the first 5000 years of emplacement. The waste package thermal analysis demonstrated that above-boiling surface temperatures are sustained for thousands of years and that these favorable dry conditions are extended by incorporation of backfill around the packages. Detailed modeling for determining the thermal history for the first 10,000 years period, with the effect of backfill, has been terminated.

\section{PLANS FOR NEXT QUARTER}

The work was discontinued after March $30^{\text {th }}$ due to project termination by DOE. Appendix 1 summarizes details of the completed tasks in a tabular form. 


\section{REFERENCES}

1. J.S. Armijo, M. Misra, P. Kar, Second Generation Waste Package Design Study, Quarterly Technical Report No. 1, October 1, 2007 to December 31, 2006

2. J.S. Armijo, M. Misra, P. Kar, Second Generation Waste Package Design Study, Quarterly Technical Report No. 2, January 1, 2007 to March 31, 2007

3. Y. N. Chang, “Oxidation behaviors of five low-alloy structural steels at $600{ }^{\circ} \mathrm{C}$ ”, Corrosion, vol. 50 (1), 1994, pp.3-10.

\section{Appendix 1. Second Generation Waste Package Design Study -- Detailed Task Plan}

\begin{tabular}{|c|c|c|c|c|c|}
\hline Milestone & Task & & Start & Completion & Status 12/31/2006 \\
\hline 991 & $\begin{array}{l}\text { ORD-FY06- } \\
023\end{array}$ & $\begin{array}{l}\text { Second Generation Waste Package Design } \\
\text { Study }\end{array}$ & $09 / 25 / 2006$ & $11 / 21 / 2008$ & Terminated \\
\hline 992 & & $\begin{array}{l}\text { Subtask 1-Definition of expected worst case } \\
\text { environments }\end{array}$ & $09 / 25 / 2006$ & $01 / 19 / 2007$ & \\
\hline 993 & & Detailed task plan & & $11 / 30 / 2006$ & Rev 1 complete \\
\hline 994 & & Meeting with Office of Chief Scientist & & $11 / 30 / 2006$ & Terminated \\
\hline 995 & & Meetings with national laboratories & & $12 / 15 / 2006$ & Terminated \\
\hline 996 & & Definition of post closure thermal history & & $01 / 12 / 2007$ & Complete \\
\hline 997 & & Definition of post closure humidity & & $01 / 12 / 2007$ & Terminated \\
\hline 998 & & Definition of post closure electrolytes & & $01 / 12 / 2007$ & Terminated \\
\hline 999 & & $\begin{array}{l}\text { Definition of reference test environments for } \\
\text { subtask } 2\end{array}$ & & $01 / 19 / 2007$ & $\begin{array}{l}\text { Premature--will reschedule in Rev } 1 \\
\text { of Task plan }\end{array}$ \\
\hline 1000 & & Subtask 2-Oxidation and corrosion tests & $11 / 30 / 2006$ & 09/19/2008 & \\
\hline 1001 & & Detailed task plan & & $11 / 30 / 2006$ & Rev 1 complete \\
\hline 1002 & & $\begin{array}{l}\text { A588 materials procurement } \& \\
\text { characterization }\end{array}$ & & $02 / 16 / 2007$ & $\begin{array}{l}\text { Material received -characterization } \\
\text { complete }\end{array}$ \\
\hline 1003 & & $\begin{array}{l}\text { Alloy } 22 \text { materials procurement \& } \\
\text { characterization }\end{array}$ & & $02 / 16 / 2007$ & $\begin{array}{l}\text { Certified Materials Procurement } \\
\text { complete }\end{array}$ \\
\hline 1004 & & Conduct isothermal oxidation tests & $04 / 02 / 2007$ & $06 / 28 / 2007$ & Terminated \\
\hline 1013 & & Complete isothermal oxidation tests & & $06 / 28 / 2007$ & Terminated \\
\hline 1005 & & $\begin{array}{l}\text { Conduct oxide thickness and compensation } \\
\text { measurements }\end{array}$ & $04 / 02 / 2007$ & 06/29/2007 & Terminated \\
\hline 1014 & & $\begin{array}{l}\text { Complete oxide thickness and compensation } \\
\text { measurements }\end{array}$ & & $06 / 29 / 2007$ & Terminated \\
\hline 1007 & & $\begin{array}{l}\text { Pretest oxidation per simulated thermal } \\
\text { history }\end{array}$ & $04 / 02 / 2007$ & $06 / 29 / 2007$ & Terminated \\
\hline 1043 & & Complete oxidation pretests & & $06 / 29 / 2007$ & Terminated \\
\hline 1006 & & Drip test equipment design requirement & & $02 / 15 / 2007$ & Design effort terminated \\
\hline 1008 & & Drip test equipment preliminary design & & $05 / 15 / 2007$ & Complete \\
\hline 1009 & & Drip test equipment fabrication and checkout & $07 / 02 / 2007$ & $12 / 21 / 2007$ & Terminated \\
\hline 1015 & & $\begin{array}{l}\text { Complete test equipment fabrication and } \\
\text { checkout }\end{array}$ & & $12 / 21 / 2007$ & Terminated \\
\hline 1010 & & Procurement of reference test electrolyte & $07 / 02 / 2007$ & $12 / 21 / 2007$ & Terminated \\
\hline 1011 & & $\begin{array}{l}\text { Pre-test thermal oxidation to prepare test } \\
\text { specimens }\end{array}$ & $07 / 02 / 2007$ & $12 / 21 / 2007$ & Terminated \\
\hline 1016 & & Complete test specimen preparation & & $12 / 21 / 2007$ & Terminated \\
\hline 1012 & & $\begin{array}{l}\text { Metallographic and chemical } \\
\text { precharacterization }\end{array}$ & $07 / 02 / 2007$ & 03/31/2008 & Terminated \\
\hline 1017 & & $\begin{array}{l}\text { Complete metallographic \& chemical } \\
\text { precharacterization }\end{array}$ & & 03/31/2008 & Terminated \\
\hline 1018 & & Initial drip tests series & $10 / 01 / 2007$ & 03/31/2008 & Terminated \\
\hline 1019 & & Complete initial drip tests & & 03/31/2008 & Terminated \\
\hline
\end{tabular}




\begin{tabular}{|c|c|c|c|c|}
\hline 1020 & Complete test specimen evaluations & & $06 / 27 / 2008$ & Terminated \\
\hline 1021 & Conduct 2nd drip test series & $01 / 07 / 2008$ & $06 / 27 / 2008$ & Terminated \\
\hline 1022 & Complete 2nd drip test series & & $06 / 27 / 2008$ & Terminated \\
\hline 1023 & Conduct 3rd test series & $04 / 01 / 2008$ & $09 / 19 / 2008$ & Terminated \\
\hline 1024 & Complete 3 rd test series & & $09 / 19 / 2008$ & Terminated \\
\hline 1025 & $\begin{array}{l}\text { Subtask 3-Second Generation WP Thermal } \\
\text { Analysis }\end{array}$ & $12 / 22 / 2006$ & $06 / 29 / 2007$ & \\
\hline 1026 & $\begin{array}{l}\text { Definition of thermal history for reference } \\
\text { YMP design }\end{array}$ & & $12 / 22 / 2006$ & Complete \\
\hline 1027 & $\begin{array}{l}\text { Definition of thermal history for2nd } \\
\text { generation YMP design }\end{array}$ & & $12 / 22 / 2006$ & Complete \\
\hline 1028 & Definition of equivalent isothermal history & & $02 / 23 / 2007$ & \\
\hline 1029 & $\begin{array}{l}\text { Backfill analysis on peak surface and } \\
\text { cladding temperatures }\end{array}$ & & $02 / 28 / 2007$ & $\begin{array}{l}\text { Complete for } 5000 \text { years, analysis } \\
\text { for the } 10,000 \text { year period terminated }\end{array}$ \\
\hline 1030 & Quantification of dry period extension & $01 / 02 / 2007$ & $06 / 29 / 2007$ & Terminated \\
\hline 1031 & $\begin{array}{l}\text { Complete quantification of dry period } \\
\text { extension }\end{array}$ & & $06 / 29 / 2007$ & Terminated \\
\hline 1032 & $\begin{array}{l}\text { Analysis of potential thermal optimization } \\
\text { techniques }\end{array}$ & $01 / 02 / 2007$ & $06 / 29 / 2007$ & Terminated \\
\hline & & & & \\
\hline 1040 & Data Submittals & 09/14/2007 & 09/26/2008 & Terminated \\
\hline 1041 & Interim data submittal (FY-2007 data) & & $09 / 14 / 2007$ & Terminated \\
\hline 1042 & Final data submittal & & $09 / 26 / 2008$ & Terminated \\
\hline 1034 & Reports & $10 / 01 / 2007$ & $11 / 14 / 2008$ & Terminated \\
\hline 1035 & FY-2007 Annual Report & & $10 / 01 / 2007$ & Complete \\
\hline 1036 & FY-2008 Annual Report & & $10 / 01 / 2008$ & Terminated \\
\hline 1037 & Final Report & & $11 / 14 / 2008$ & Terminated \\
\hline 1038 & LSN Records submittal & & $11 / 21 / 2008$ & Terminated \\
\hline 1039 & End of funding & & $09 / 30 / 2008$ & Terminated \\
\hline
\end{tabular}

